\title{
ERRATA
}

\section{Synonymy of Pseudomonas avenae Manns 1905 and Pseudomonas alboprecipitans Rosen 1922}

\author{
N. W. SCHAAD, C. I. KADO, AND D. R. SUMNER
}

Department of Plant Pathology, University of Georgia, College of Agriculture Experiment Stations, Experiment, Georgia 30212; Department of Plant Pathology, University of California, Davis, California 95616; and Department of Plant Pathology, University of Georgia, Coastal Plain Experimental Station, Tifton, Georgia 31794

Volume 25, no. 2, p. 133, title: "Manns 1905" should read "Manns 1909."

Page 135, column 2, lines 21 and 22: Paragraph lead should read "Description of ATCC 19860." Page 136, column 1: Lines 21 through 23 should be deleted.

Taxonomic Study of Bacteroides clostridiiformis subsp. clostridiiformis (Burri and Ankersmit) Holdeman and Moore and of Related Organisms: Proposal of Clostridium clostridiiformis (Burri and Ankersmit) comb. nov. and Clostridium symbiosum (Stevens) comb. nov. CHOJI KANEUCHI, KEIKO WATANABE, ATSUSHI TERADA, YOSHIMI BENNO, AND
TOMOTARI MITSUOKA

Institute of Physical and Chemical Research, Wako, Saitama 351, Japan

Volume 26, no. 2, p. 195-204: "Clostridium clostridiiformis" should read "Clostridium clostridiiforme."

\section{Brochothrix, a New Genus Tentatively Placed in the Family Lactobacillaceae}

P. H. A. SNEATH AND DOROTHY JONES

Department of Microbiology, The University, Leicester, England

Volume 26, no. 2, p. 102, column 2, lines 22 and 23: "Microbacterium thermosphactum OrlaJensen" should read "Microbacterium thermosphactum McLean and Sulzbacher." 